\title{
Requiem of a Con: Robert Sullivan's Letters To Nancy Picthall From Death Row
}

\section{Laurence French and Nancy Picthall-French}

In a narrow 5 to 4 decision, the United States Supreme Court (USSC) held in 1972 that the imposition of the death penalty was conducted in an arbitrary and capricious way and, therefore, constituted cruel and unusual punishment (Furman v. Georgia, 1972). While this action effectively cleared the nation's prisons of their death row population, public sentiment for capital punishment, much of it fostered by the political turbulence and social anomie of the 1960s and 1970s led to a renewed interest in the death penalty. Thus, in 1976 the USSC again sanctioned the death penalty. Now the trial process involves two stages: (1) the regular petite (adversarial) trial process, and (2) a second hearing to review possible factors which may have influenced the condemned individual's behaviour relevant to the commission of a capital crime. With this new 'objective' method of adjudication in place, the wheels of the execution process began to creep forward following a ten-year moratorium on legal executions between 1966 and 1976. The first execution involved a volunteer Gary Gilmore - who was executed on January 17, 1977 by a Utah firing squad. John Spenkelink, the first unwilling prisoner to be executed, met his death atop "Old Sparky", the Florida electric chair, on May 25, 1979. Robert A. 'Sully' Sullivan followed Spenkelink to the electric chair on November 30,1983, making Florida the first state to host consecutive executions since the reinstatement of capital punishment in the United States. Sullivan was the eighth execution overall. He also held the dubious distinction of having served on death row longer than anyone. Even a rare personal plea for clemency from Pope John Paul II was denied by then Governor - and now U.S. Senator - Graham. 
The Sullivan case illustrates the most glaring flaws in the capital punishment process, and how abuses can be manipulated by agents of the criminal justice apparatus. A review of the case clearly indicates that Bob Sullivan did not receive a fair trial. More significant is the fact that the judicial system was manipulated from a number of sides to falsely implicate him. Why? After all, Bob Sullivan was from a Caucasian, upper middle-class family. Most studies of judicial discrimination within the United States suggest that working class and racial minorities such as Blacks, Hispanics and Indians are more likely to receive unfair treatment and harsher sentences. Why then was $\mathrm{Mr}$. Sullivan considered fair 'bait' for exploitation? How was he expendable? That is, why was he considered to be beyond redemption? The reason is that he was homosexual - a fact skirted in the testimony, yet quite obvious. It was this prejudice, we contend, that allowed justice to be abused in this case.

\section{A CASE STUDY IN THE POLITICS OF DEATH}

On April 11, 1973, the body of Donald Schmidt was found in a swamp near the Howard Johnson restaurant where he was employed as the shift manager. He was shot twice in the head with a shotgun. Apparently, his death occurred on the night of April 8 after the restaurant closed. The last person to see Schmidt alive was his supervisor, Frank Barden. Neither Schmidt nor Barden had ever met Bob Sullivan; nonetheless, Barden led police to Sullivan, a former manager of the restaurant, who was dismissed in June, 1972.

Interestingly, Frank Barden, the one who implicated Sullivan, was the police's prime suspect since he was th last to see the victim alive. Barden was a state witness before the Grand Jury that indicted Sullivan. He than disappeared with six days worth of cash receipts from the restaurant. Found by the FBI in Las Vegas, Barden was returned to Florida and was offered probation if he continued to implicate Sullivan during his petite trial. Convinced that Barden was the mastermind behind her husband's murder, Mrs. Schmidt filed a Federal Civil Suit against him. He remains free today.

One of Sullivan's room mates, Reid McLaughlin, turned 
Journal of Prisoners on Prisons, Vol. 3, No. 1/2, Spring, 1991.

state's evidence for a reduced non-capital charge, and was released prior to Sullivan's execution in 1983. Another room mate and suspected accomplice with McLaughlin and Barden, Gilbert Jackson, was found executed in Boston in 1978. He had been killed in the same manner as Donald Schmidt, and died just as he was being sought as a witness by Sullivan's defence league in the attempt to obtain a new trial for Sullivan. Since Sullivan was on death row at the time, he could not have committed this crime and the similarity of the two murders casts doubt upon Sullivan's guilt of the first murder.

Equally disturbing was the role that criminal justice agents played in the obstruction of justice in the case. Among the primary actors is Warren Rudman, a politically motivated New Hampshire Attorney General, who provided a bogus New Hampshire warrant which allowed the Florida police to arrest Sullivan for theft.

Another actor, police investigator Sergeant Felton, denied Sullivan his basic rights and used questionable interrogation tactics to secure an error-ridden confession. Ira Dubitsky, prosecutor in the case, allowed McLaughlin and Barden to provide dubious testimony as part of a plea bargain while trial judge, Edward Cowart, showed extreme prejudice in the case by failing to allow the testimony of at least five witnesses who placed Sullivan at a homosexual bar some thirty miles away at the time of Schmidt's murder. In his letter of March 21, 1981, Sullivan notes that Judge Cowart influenced the proceedings by threatening the Clemency Board in a letter stating that he would resign his position in protest if any consideration were given to Sullivan.

Sergeant Felton was promoted to chief of the Dade County Homicide Division and prosecutor Dubitsky was appointed as Dade County Circuit Court Judge. And while Sullivan was executed, Judge Cowart became the Chief Judge of Dade County who amazingly was willing to allow Ted Bundy, serial murderer, to plea bargain for a life sentence. While Judge Cowart threatened to resign if a homosexual such as Sullivan were given consideration, his words to Bundy in court after 
sentencing to death included:

"Take care of yourself. I say that to you sincerely. It's a tragedy to this court to see such a total waste of humanity. You're a bright young man. You'd have made a good lawyer. I'd have loved to have you practice in front of me" (Larsen, 1980:321).

Clearly, Cowart's sentiments towards Sullivan were far less considerate, a curious distinction given the differences in the crimes for which Bundy and Sullivan were convicted.

Adding insult to injury, Sullivan's court-appointed defence lawyer, Denis Dean, was incompetent. He failed to bring forward important evidence in mitigation, a point which formed the strongest basis of Sullivan's unsuccessful appeals, and he failed to call relevant material witnesses. It was later disclosed that he was pro capital punishment. In Sullivan's attempt to secure a retrial, it was stated that Denis Dean became the State's star witness and did his best to sabotage any chance of Sullivan winning his case. Given the actions of all of these individuals, and especially Judge Cowart's influence and the Governor's political motivations, it can be strongly argued that Bob Sullivan never received a fair trial.

\section{A WINDOW TO DEATH ROW: LETTERS TO A CHILDHOOD FRIEND}

Robert A. Sullivan was the adopted only child of an affluent family which resided in Belmont Massachusetts, a small Boston suburb where the faculties of Harvard University and MIT raise their families. Nancy Picthall and Bob Sullivan attended Belmont schools in grades one through twelve. Once Bob was on death row, they began to correspond.

The correspondence consists mostly of letters. Occasionally, printed 'Updates' and 'RAS Memos' were sent to 'catch up' or pass on the same information to supporters. In this correspondence, we are given a unique opportunity to indirectly observe the horror of death row and one man's attempt to maintain his struggle for life despite a host of setbacks which ultimately result in his death. As we observe Bob Sullivan 
Journal of Prisoners on Prisons, Vol. 3, No. 1/2, Spring, 1991.

through this window of correspondence, we sense the urgency of the conditions he must endure. Clearly, his personal relationships figure prominently in his resolve to maintain that struggle, in the face of the personal and legal crises which arise during his ten years on death row. The corrspondence speaks for itself.

INSTITUTION

NAME
FSP

Robert A. Sullivan

JOB ASSIGNMENT Death Row
CELL NUMBER $\underline{\mathrm{R}-1-\mathrm{N}-8}$

NUMBER

$\underline{039870}$

$5 / 13 / 79$

Dear Nancy,

Thank you very much for your latest letter. On a very hot (90's) Sunday afternoon, my spirits are quite good. I have spent an exceptionally busy weekend writing and working on various projects for my defense fund and for $\mathcal{M r}$. Black's use at my Clemency Hearing which is scheduled for this Friday, 5/17/79. $\mathcal{A}$ fter a long period of procrastination, we finally decided to send a statement about my situation via a direct mailing to my former figh school classmates. In addition, after getting input from my key defense fund advisors, I combined these drafts into a statement that we can use to distribute to interested parties, the media, etc. I think that it reads very well and it should be effective.

On Thursday, 5/3/79, Mr. Black and his law clerk were here to confer with me for $51 / 2$ hours about my case in general and to make out our final plans for our clemency presentation. On $5 / 9 / 73$, another lawyer, Debbie Sims of the $\mathcal{L D} \mathcal{D}$ was here to see several death row inmates. From $\mathcal{M r}$. Black I learned that my 3.850 motion had been assigned to Judge Ellen MorphoniasRowe, that she only was willing to hear the ineffective counsel point in an evidentiary hearing, and that she ruled against us on all points. I really expected a loss on this state court level, but I had hoped for a better hearing. But there should be a silver-lining here because Black feels the Iudge screwed up badly especially since she refused to let me testify about my ineffective assistance 
of counsel and I surely was the defense's key witness. My previous appointed attorney, Denis Dean, was a state witness which was very disappointing. Black wrote of the Hearing thusly; "Dean did his best to sabotage any chance that Bob would have for success." Black also wrote that, "I really found it quite depressing that Dean found it more important to save his little face rather than Bob's life."

What disturbed me the most about Dean's actions was the fact that he saw fit to lie and misrepresent facts to try to protect his image. Iustice and fair play have been non-existent in this case which really bothers me. I am getting tired of State witnesses lying repeatedly, and as a result, to combat Dean's lies, we should have a few tricks. I realize all too well, that my attitude must sound like sour grapes, 6ut I must say that I am 100\% in the right. Black was as disgusted with Dean as I was myself which helped me to feel somewhat better.

Black remains optimistic that my appeals will be successful, and our argument against Dean is a strong one. If need be, we may see if a court would look favorably upon a polygraph test, which I'd gladly agree to take. My case will be fully appealed to the Florida Supreme Court. Rather than rule on my case, Mr. Black feels that this court will instead remand my case back to the Circuit Court and order that I have a full evidentiary hearing where I am called as a defense witness.

Besides the appeal movements and clemency preparations, we covered my case in full. As a result of our conversation, Thomas Murphy was located at long last. I learned on Friday, his is a lawyer and one of my best alibi witnesses. For clemency, after we heard feedback from earlier hearings, we revised our original game plan to stress the favorable parts of my life rather than only the legal issues as the best means to successfully impress the Governor. I feel quite comfortable with our final plans and I hope for the best. 
Journal of Prisoners on Prisons, Vol. 3, No. 1/2, Spring, 1991.

Black left me with alot to think about in two areas. He really stressed the importance of being able to afford a much fuller investigation would contribute to winning my case. Naturally, a lawyer is more effective to raise the $\$ 10,000$ - that is estimated we need, an amount that almost made me choke. Also, Black asked me what I could do to cover a bond when (not if) I get a new trial. He remarked frow much help I could be to the defense if I was out of jail, which makes alot of sense, but I have no idea how I could cover a bond? In any event, he left me with much to think about, didn't he?

I enjoyed your letter very much and thanks for including the stamp which does help me. Yes, I do try to make the best of it in this pressure cooker of unique circumstances. Your office group sounds like a nice group to work with. I always tried to surround me with people I liked since it would be no fun to work 40 fours per week or more around people one cannot get along better than normal. I will get a flyer sent to you as soon as the newest one is prepared. Please remind me the next time that you write.

Hoping this finds you well.

As ever,

Bob 
Dear Nancy,

Thanks for your letter! On a 96 degree day, I am well and in fine spirits. It won't be long until we are complaining about the cold weather instead of frot. I am pulfing hard for the Red Sox to catch Baltimore; with 39 games to play, the Sox are $41 / 2$ "tough" games befind. I am excited about the soon to commence pro football season. As usual on Labor Day, I plan to view most of the Jerry Lewis Telethon. Annually, the Telethon is a healthy emotional release for me since I usually suppress my outward emotions.

Even though I am fully caught up with the "death watch" work accumulation, I have much that keeps me occupied. For the most part this week, I have been thoroughly reviewing all my legal files and notes which fill 3 full boxes, for the purpose of advance preparation for Ray's visit here which ought to be within the next 2 weeks. Since this will mark only my second face to face meeting with Ray it is important to me to make the most of every minute while he is here.

$I$ also have been rereading and reorganizing the notes and manuscripts which I'll use to finish writing my book. Over this weekend, I intend to make a outline on a chapter by chapter basis. My intention is to jump into the book writing heavily in the coming months, aiming to complete the manuscript for a publisher's consideration by 1/1/80. Acquiring a publisher's attention may not be quite so easy. I have 80+ new pages covering the Spenkelink execution and my experiences while on the death watch, which will form a solid core for my book.

Rolling Stone remains keenly interested in publisfing part of my manuscript about the death watch. I am anxiously awaiting a further update from the person who is editing it for me. In addition to the regular Boston papers there has been reasonable publicity elsewhere. The Boston Phoenix did a lengthy piece about my struggle as it's cover story in early July. The next known article will appear in September's Fortune Society, 
Journal of Prisoners on Prisons, Vol. 3, No. 1/2, Spring, 1991.

Fortune $\mathcal{N}(e w s$, written by it's director David Rothenberg which also will request contributions. Rothenberg hopes to write another article for publication consideration. The ball fias started to roll with greater media exposure which we hope will continue.

Based upon what I've been told, The Douglas case will be the lead $\mathcal{F l o r i d a}$ case. This determination stems from the fact that his case will probably be the first case to advance beyond the Federal District Court. Although Ray is back from his vacation, he has not reported anything significant to me on my case. We will get everything discussed when Ray comes to see me before flying to Boston to meet with my supporters.

Politics is slowly increasing in tempo now that the primaries are inching closer. I know that Carter is vulnerable from within fis own Party. I am both puzzled and disappointed that my top choice, Jerry Brown, has not yet mounted a real challenge. If Brown is unable to beat Carter, I then hope Ted Kennedy enters the campaign in ernest. I prefer a liberal social-issue President, one who also is a fiscal conservative. Brown parallels both positions, leadership wise, Carter has been much less than I anticipated, but he serves during rough times. If Brown fiopes to emerge on top, now is the time to mount fis charge. Meanwhile, no Republican has emerged out of the pack to take a lead. Both Party races ought to be interesting; who do you expect/want to win in 1980?

I will include a $\mathcal{B H S}$ flyer - if you wish additional information, please write to Barry Weaver. I am glad that you wrote again. Since your father sent you clippings, I guess you know about my week of pure hell.

I hope this finds you well - please write again soon.

As ever,

Bob 
September 10, 1979

Monday

Dear Nancy,

Thank you for your long letter. All continues fine with me. I am catching up on my correspondence having been lazy over the weekend viewing all the football games. I was scheduled to have frad a visitor on Friday on a social basis, Middlesex County's (Mass) Sheriff Jofin Buckley. The prison neglected to send $\mathcal{M} r$. Buckley a confirmation that he could see me so he altered his plans. I really hope that he can reschedule the visit, since Buckley could be a strong ally for us due to fis position in the organization, Law Enforcement Against the Death Penalty.

Having heard from Ray Black, I am anxious to see his efforts with the merit of certiorari to the USSC which he is drafting now. It is important to realize that the USSC rarely accepts for full review an appeal of a State habeas corpus proceeding. As is the court's option, it carefully chooses certain issues to review on this level. Non-acceptance at this stage by the USSC definitely does not mean the issues lack merit? For example, on most issues, if the law is already clear, the USSC prefers instead for the lower Federal Courts to tackle the appeal. It appears that we are on secure ground with Iudge Gonzalez. I am pleased that we'll have the opportunity to try to tie up more loose ends in my case such as locating Thomas Murphy before we appear in front of Iudge Gonzalez. Due to his busy schedule, Ray has not yet been able to set aside the time necessary for a dual visit, first to see me and thereafter to Boston.

Steve Gettinger did a marvellous job editing my "death watch" manuscript. The present form consists of 25 double-spaced typed pages. It reads smoothly and packs quite a punch. In addition, Steve will write a companion article about me which will make quite a comprefiensive package. Let's hope Rolling Stone accepts it fully.

There is some good news to share. The raffle conducted by the Belmont chapter of my defense fund was a huge success. The final tabulation greatly exceeded my expectations. The proceeds 
Journal of Prisoners on Prisons, Vol. 3, No. 1/2, Spring, 1991.

were \$1169. Isn't that super? I am a lucky man indeed to have such wonderful, loyal friends who give so much of themselves for me. Earlier, I set a goal of $\$ 10,000$. by $1 / 1 / 80$, and now I believe we'll make it. The raffle proceeds put us over $\$ 8000$, a figure which reflects every dollar raised since the creation of the defense fund in 1977. Based upon the very solid case advances during the last 18 months, we've certainly invested our funds wisely, I'm sure you'll agree? But the/our fight has only just begun.

I received an interesting mailogram from Iim Mitchell, who is affiliated with the authorities in the Mass. investigation. He states that Barden's name came up in their investigation with links to the same Boston lounge where McLauglin was employed! You can bet that I'll try to get this matter followed up, a issue that most of us knew previously. Also, he asserts categorically that he does not feel the gackson murder case was satisfactorily handled, plus he acknowledges that Jackson could have been murdered to silence fim. Mitchell's closing sentence merits quoting for you; "We firmly believe in your innocence in the Schimidt case."

Please don't feel that typing is offensive to me! It is not. I'd type my letters if these people would allow me to have one. Your visit to England sounds as if it was great.

I fope all is well with you -

As ever,

Bob 
Laurence French and Nancy Picthall-French

October 14, 1979

Sunday

Dear Nancy,

Thank you for your letter. I remain well and in good spirits. We finally have received some delightfully cool weather, much to my delight after the long, fot summer. Like any real sports fan, I am in sports heaven now with activity on 4 fronts including the World Series. There is little important legal news to share. We still plan to file in the USSC next, prior to any hearings occurring in front of Judge Gonzalez.

Ray Black's schedule has been so crammed that he still has been unable to get up to see me and continue on to Boston to meet with my defense fund supporters. Generally speaking, the USSC has rejected 6 more Florida cases. However, the USSC has accepted 1 case apiece from Georgia and Alabama respectively which challenges portions of those states' capital punisfment laws. In addition, the Governors Office announced that 3 more cases would fave their Clemency Hearings on 11/5/79, which no doubt will be the forerunner to the signing of more death warrants in the near future. As far as the case investigation is concerned, I have learned that Ray is currently pursuing a strong "prize lead" fere in Florida attempting to relocate another of our potential alibi witnesses. You can believe that my anxieties are intensified while waiting on more information. Waiting is damn rough! Life on death row while zealously trying to prove one's innocence surely is like a roller coaster ride on a man's nerves and emotions.

$\mathcal{M} y$ case has received some additional publicity. Dave Rothenberg of the Fortune Society wrote a column in the Fortune News dealing with capital punishment. Therein, Dave touched onto my plight. He stressed the guilt vs. innocence issue in my case both forcefully and favorably as well as indicating that inquires should be directed to my defense fund. We hope for a reasonable response since the circulation exceeds 31,000. Dave is fighly respected within segments of the Criminal gustice system.. He intends to draft another article soon for placement elsewhere, probably in the Advocate. As you can see, we continue to forge ahead slowly securing additional favorable media exposure. 
Journal of Prisoners on Prisons, Vol. 3, No. 1/2, Spring, 1991.

Resulting from a lawsuit settlement, I/we have reacquired our "contact" visiting privilege. I am trying to have my cousin Deb6ie, who resides in Jacksonville, placed on my approved visiting list. Incredibly, the Classification Department denied my initial request, nevertheless, I fope to find some way to work around it. Speaking of visits, the on-again off-again visit with Sheriff John Buckley of my home county in Massachusetts is back on again. Even though he has permission to see me, before he finalizes fis plans, he is awaiting an answer to fis request attempting to secure an appointment with Governor Grafiam. I am naturally wondering if and how the meeting with Grafiam might concern my case! Much more realistically, I suspect that the meeting probably has more to do with the position of the organization, Law Enforcement Against the Death Penalty, in which Buckley is actively involved.

I have not heard directly from Stephen Gettinger since early in September. I am still fropeful that my death watch manuscript will be accepted by Rolling Stone. However, last week I received Steve's new book "Sentenced to Die" indirectly via Susan Cary Esq. I immediately read the book from cover to cover. It was engrossing reading! On the inside cover, Steve wrote a touching note to me, "Io Bob - You're fighting for our souls too. Best regards, Steve G.". One day, I too fope to have a book published dealing with my years on Death Row, thus joining Caryl Chessman and Edgar Smith as published death row authors.

How is the new girl working out at the office? As a manager, whenever I was trying to fill a position, if I was unsatisfied, I'd continue to make changes until I was satisfied. I'd prefer to train than be frustrated by incompetence provided the individual had a fair chance to adjust to the job description.

I am allowed 1 pre-approved package of allowable items each month. My next 2 packages are the Xmas food packages. By January, I may be very much in need of certain items. If you'd care to consider filling a package, please let me know and we can start to agree on the items - we can get up to 4 items approved per package. 
I am indeed an avid football fan. Although I much prefer Pro football, I do follow the major college teams. Nebraska surely falls into that category. The Cornhuskers could and in fact should go into the OKlahioma game undefeated. We"ll see.

Among other members of the BHS Class of 1965 who are active with my defense fund are Linda Radin and Janis Forde. Jack Golden has been a help but to a lesser degree. I guess when compared to other school systems, we all had a rare opportunity at better education. I am surprised that some of our classmates haven't become better known positively. Ironically, and surely in a negative sense, I have probably gained more notoriety than anyone else. It is a very, very dubious distinction and it is most definitely unwanted. The next class reunion (1980) will mark 15 years since we graduated. It will be interesting to see who shows up and what they have achieved in life. If I am still in this lousy position, we'll probably try to get some sort of organized plea connected with the class reunion.

I do hope this finds you well.

As ever,

Bo6 
Journal of Prisoners on Prisons, Vol. 3, No. 1/2, Spring, 1991.

December 10, 1979

Wednesday

Dear $\mathcal{N a n c y ,}$

Thank you for your letter. I am well and my spirits are very high. The fast pace of recent events has really perked me up. I do not expect the pace to relax until after the $\mathcal{F} D C$ hearing. Even though no date has been set, the hearing should take place within the next 30 to 60 days. There is a massive amount of preparation required for both Ray and myself before the hearing. Ray and our new investigator, Virginia Snyder (she seems quite sharp), spent all day on Friday with me. We had a comprehensive discussion about the upcoming hearing as well as the areas to be investigated. This discussion was both positive and productive. It appears that we have a very good chance to be granted a new trial on the ineffective counsel point, among others Ray feels confident of being able to prove my innocence at a new trial.

It strongly appears that my defense is moving closer to a collaboration with Mass. whereby they assist us to demonstrate that their suspect in Mass. was responsible for planning the set up to frame me which was implemented by Mr. Laughlin, Borden, and gackson. We have 3 new, detailed affidavits to support this conclusion. In addition, most signs point toward the suspect engineering 6oth the Jackson murder and the Brill death. (See enclosed Memo). Mass. was here to see me on Tuesday and they are supportive of our speculation. Brills contact with the suspect and his keen interest in the Jackson murder adds fuel to the fire. It appears that a connection exists linking everything together, all pointing to the suspect.

Our investigation will be working on the Mass. connections. Also, she will follow up the new lead to Thomas Murphy (it appears a Boston Globe reporter found him for us), try to locate all the other potentially helpful witnesses, and attempt to uncover additional favorable evidence such as the unmatched footprints at the murder scene. We have been told that Murphy is uncooperative, fearing getting involved. Contrary to what Murphy had led me to believe, he is mad at lawyer. Oddly enough, he was employed by the Massachusetts Department of 
Corrections. However, fis brother is a lawyer. Somefiow, we must effectively reach that man on some level, he is clearly by potential, our most important alibi witness.

Overall, I'd say that things are certainly looking better. If we can convince Murphy, assuming he is the right one, to step out into the open we'll be in much better shape at every future legal proceeding. This may be where the investigator can repay large dividends. Furthermore, I am positive that much favorable data exists merely waiting to be discovered.

I am elated that, Rolling Stone accepted my manuscript titled, "Death Watch." I received the contract agreement on Friday I am having the entire fee sent to my defense fund. I think that you will find it excellent reading. Steve Gettinger, who did the editing, also will write the introduction. The death watch in Iune was an experience that I will never forget, coming so close to being executed. This manuscript is by far the best material that I have ever written. I understand that Rolling Stone's editors were very impressed with the manuscript. I am hopeful that the article will stimulate additional interest in me and my plight. The Cincinnati concert tragedy fras postponed my piece for at least 1 issue since mine will be a feature article, I understand. I will try to keep you informed as more information becomes known about the article as well as other developments.

It was good to hear from you once again. Has there been any word on a 15 year $\mathcal{B H}$ S class reunion 65-80? Did you attend the one in 1975? I very much appreciate your willingness to send me a package. I am limited to 4 items per permit and I must submit in advance (ganuary) a permit form to get the items approved. Therefore we should discuss them. I'd like a pair of rubber thongs (shower slides) size 12, 4 long yellow legal pads, envelopes 100 business size and 10 each of medium and $9^{\prime \prime} \times 15^{\prime \prime}$ approx. size large Manila envelopes. The 4th item is more expensive and if it is too much then we can switch to (two XXL grey sweatshirts) but my preference (by need) is a new headphone set. If there is a Radio Shack there, please get a №VA-PRO Stereo headphone (catalog \#33-1014A) in the Realistic line. Headphones are my escape from all the noise and my pair is on its last legs. Please let 
Journal of Prisoners on Prisons, Vol. 3, No. 1/2, Spring, 1991.

me know on this so that I can let you know when, etc. I can't submit the permit til January 1 anyway. Thank you.

I frope you folidays are enjoyable.

As ever,

Bob

December 26, 1979

Wednesday

Dear $\mathcal{N a n c y ,}$

How were your fiolidays; pleasurable I fope? I am well and in good spirits, but busy as usual. I am devoting much of my time to the preparation of myself to testify at my Federal District Court $(\mathcal{F D C})$ hearing which is just over the horizon. My goal is to be the best possible defense witness. Judge Kyle, the Federal Magistrate, will issue a lengthy pre-hearing order on my case soon. The actual hearing should be feld within the next 60 days. Kyle will monitor the case, conduct the fact finding evidentiary hearing, and thereafter make a recommendation to Iudge Gonzalez, the latter of whom will render the final decision. It appeared to Ray that Iudge Kyle has taken a very active interest in my case and is aware of all the facts and circumstances. Ray feels that we will finally have a "fair hearing" at long last.

Ray has impressed upon me that I will be on the witness stand for at least 1/2 day. My testimony is vital and I remain confident that I can handle the associated pressure. Much of my testimony will surround the ineffective counsel issues. In addition to myself, we will call several other witnesses including our alibi witnesses. I will only be gone to court for the duration of the hearing, after which I will be returned to the prison. Please continue to send all mail here to the prison, fowever, while I have gone to court I will no doubt be too busy to write many letters. Naturally, I will keep you informed when I write of happenings leading up to the hearing as well as a full report afterward. We are optimistic of securing a new trial. 
Had I told you previously that Rolling Stone accepted my "Death Watch" manuscript? $\mathcal{A}$ late January publication is probable. It really gives me much satisfaction to finally be able to directly help the defense fund drive, plus the exposure should be favorable. Including the thousand dollar fee for the manuscript, defense fund contributions have exceeded $\$ 11,300$ since its inception. Additional fund raising efforts are of paramount importance at this stage since Ray has fired 6oth a private investigator and a criminologist to assist fim. This vital backup support must be maintained since their contribution can significantly improve the defense effectiveness.

The new investigator, Virginia Snyder, is already at work checking aspects of the case. Besides trying to locate additional witnesses and approach Thomas Murphy seeking his cooperation, Virginia met a Mass. official on 12/18/79. This official will meet with Ray and Virginia later this week in South Florida. These meetings will exchange evidence as well as determine the extent of Mass. Felping me. Some focusing will naturally be on the Jackson murder and the Brill death. Although they believe I was framed, we still need hard facts to demonstrate it to others. The criminologist will examine all the evidence and prepare a report detailing everything favorable. This activity will parallel what Paul Kirk did for Dr. Sam Shepard, which substantially contributed to Shepard's acquittal. As you may recall from the defense fund literature, every piece of the fiard physical evidence from the crime scene is in conflict with the State's case; the evidence supports my innocence rather than my guilt.

Thank you for the Xmas card. Yes, we do have heat in the building but it is not a great system. I don't mind the cold so it really doesn't bother me. Please let me know of any changes on the package. I will proceed accordingly seeking the permit from my end after the 1st.

Best wishes for the New Year. 
Journal of Prisoners on Prisons, Vol. 3, No. 1/2, Spring, 1991.

January 14, 1980

Dear $\mathcal{N}$ ancy,

Thank you for your latest correspondence. To accompany the permit (comments [sic] later) I wanted to bring you up to date with happenings. Having devoted much time to pre-hearing preparations reviewing my case documents, I am feeling more confident all the time about my knowledge retention level. There is so much to the entire case, that my testimony alone will be quite lengthy. I'd much prefer to be over-prepared than the opposite due to the figh stakes.

I remain well and in good spirits even though I am already missing the Garrage of televised football games. Before the basketball season can completely take over, the Super Bowl still remains. I look forward to the game even though I strongly favor the Pittsburgh Steelers both winning and covering the (-10 pt) spread.

On Thursday, I had a picture taking session with a photographer dispatched by Rolling Stone. It appears that my article is moving closer to publication. Even if you should miss it, we'll have copies available. Accompanying my 7000 plus word article will be an introduction which I hope is both meaningful and favorable.

I have not received any more news about Iudge Kyle's prehearing order. The wait has me a shade anxious. Thankfully, Virginia Snyder, our investigator, is Keeping me updated on ker activities. She has had frequent phone conversations with Mass. investigators. One is coming to Florida to meet with Ray and Virginia soon. I was told that he has some exciting news to relate to us; afterward he will come to tell me in person as well. I believe that this news could be some hard facts to support my long-standing suspicion that Jackson's $8 / 28 / 78$ murder motive was to prevent my lawyer from confronting fim about my case. We already possess a growing file of sworn affidavits to support this conclusion. Besides the "exciting news", I plan to raise many other subjects. 
Among Virginia's other primary objectives is to coax one of our recently found alibi-type witnesses, Thomas Murphy, into being a "willing" defense witness. We have located his S. Florida winter residence. However, he refused to talk with Virginia when she went to his home. Apparently, he fears getting involved which I can relate to somewhat. Attempting to dispel these fears may not be easy, nevertheless, we aren't about to give up after struggling for $63 / 4$ years simply to find him. A carefully worded letter has been sent to him requesting a meeting at his convenience. I pray that he'll meet with Ray and Virginia. We will do our collective best to find the way to convince the witness to cooperate.

Let me switch subjects to politics. I was keenly interested in the Republican debate in Iowa despite Reagan's absence. Except for Dole, all the candidates impressed me for various reasons. I say this even though my position is miles apart from the traditional Republican platform on social issues. I was disappointed that the Democratic debate was cancelled. Because Kennedy has made some verbal blunders and slipped behind Carter in the polls, I really wanted to see these 2 men square off debating the issues. I strongly suspect that Iran and Afghanistan backlash will be a large negative 6lot on Carter's foreign policy report card. Parts of our world are in turmoil and I do not feel that Carter is the right person to lead our nation into the 80s! I frope that Kennedy and Bush have strong showings in the Iowa caucus upsetting Carter and Reagan respectively.

Two more Florida death warrants have been signed, both to blacks under the new, longer grace period, the scheduled executions are not set until 2/13/80. I am confident that both will receive stays. I am alarmed by the bad attitude by my peers. Most men seem to sweep it out of their minds, rationalizing that it can't or won't happen to them. For anyone on Death Row, that is unrealistic! It appears that Governor Grafiam will sign at least a dozen new death warrants in 1980, fowever, I don't foresee any more Florida executions until 1981, when several cases could run out of appeal options. 
Journal of Prisoners on Prisons, Vol. 3, No. 1/2, Spring, 1991.

As you can see, I have included an approved package permit. Please note that it must be included inside the package and it is only good for 30 days. Let me go over each item once again with some minor revisions.

1) Shower slides - - (rubber thongs) - my size is 12ish. I'd prefer the thicker sole style.

2) Headphones - Catalog \# 33-1014A is the model that I have which served me well. Nova-Pro-Stereo from Radio Shack. (Or similar model)

3) Paper - please send 6-8 yellow legal pads (prefer long style)

4) Envelopes - 100 reg. Business size envelopes

20 assorted large manila envelopes

12 large size file folders.

I very much appreciate your help with the package.

Take care and,

$\mathcal{A} s$ always,

Bo6 
Dear $\mathcal{N}$ ancy,

Please excuse the Grevity and tone of this letter, fowever, I am confident that you'll comprehend the reason(s) once you finish reading? For the next 3 to 4 weeks, my correspondence will be tardy. Most of my time must be devoted to legal matters and $\mathcal{F D C}$ hearing preparations.

On Friday, I received two important, long awaited pieces of mail. Jay Merritt of Rolling Stone sent me copies of issue \#312 which contains my manuscript among the feature articles. Also, Ray Black wrote me about and included a copy of Judge Kyle's pre-hearing order. Interestingly, the issue's cover date and the hearing date both are March 6, 1980. I hope this is a good omen? Both Ray and I will be working hard to prepare for this hearing.

The time has come; it is now! I/we have been awaiting this critical hearing for a long time. My future should be clearer as a direct result of this ruling. Among our dozen appeal points, Iudge Kyle has concluded that additional testimony will be necessary on 3 points. Our other points apparently are already sufficiently clear from the trial record on which to make rulings based upon the law. The points on which Iudge Kyle will accept additional testimony are; (1) a due process challenge to determine whether or not the State Circuit Iudge erred by refusing to let me be present and testify at the State hearing; (2) of (3) will determine if Windsor's and/or Dean's respective representation was ineffective? These three issues as well as several of our other points are sound appeal points. Besides ineffective counsel, our strongest legal issue is an erroneous trial reference by McLaughlin inferring that he passed a polygraph test. In reality, McLaughlin failed the test!

On Tuesday, I spoke briefly with Ray by phone. He filled me in on some details, however, we deferred making any final decisions until after we confer together prior to the hearing. Ray felt that the article turned out very well. Ray will ask Kyle to order that my transfer south occur no later than one week prior to the fearing. Once the hearing concludes, I will be returned to Death Row. Then the hard part starts while awaiting Kyle's 
Journal of Prisoners on Prisons, Vol. 3, No. 1/2, Spring, 1991.

recommendation to Iudge Gonzalez. The final disposition rests with Gonzalez. This procedure could consume several months until after the hearing, everything including social correspondence will have to take second fiddle. Legal preparations must be my exclusive priority which I hope you can understand? Please continue to send your welcome letters to this address.

The Rolling Stone article commenced sale on 2/19/80. When you locate a copy, I'd welcome your candid impressions of the material? Except for one unfortunate mistake, one that could have a silver lining effect, I felt the entire package turned out superbly. Due to an exfiausted defense fund account, I hope and pray that our plea for contributions generates a solid response.

Earlier today, the property room officer safely delivered the package. I want to sincerely thank you so very much for your time, trouble, and expense to send these items to me. The headphones are perfect and very much needed. It will be a welcome relief again, thru the use of the headphones, to obtain quiet from my peers. Noise can distract me from my work. Their arrival now is especially timely to enable me to study my case files in preparation for my testimony at the Federal hearing. The stationary items are very helpful as well.

When time permits, I will keep you updated. In the meantime, please Keep your letters coming to this address.

Thanks again, and,

As always,

Bob 
Dear Nancy,

After attending my $\mathcal{F}$ ederal hearing, I have been returned to the prison. I will attempt to discuss the hearing's highlights for you, although you should know that I am so close to the case that objectivity is difficult. Moreover, my own testimony consumed many hours time so it would be almost impossible to weigh the impact. Susan Cary reported to Richard Greene, another attorney, that I did well on the stand. Several other friends who attended the hearing all informed me that I came across well despite a very intense, lengthy cross-examination.

Transportation each way was via private plane. Most county jails, including Broward's, are lousy facilities. Even so, the change of scenery away from Death Row was quite welcome. Surprisingly, I was placed in a regular bullpen cell. It was difficult to be around so many people again. This was my first "vacation" since my arrival at Starke in November, 1973.

I was away for over two weeks. I am slowly getting caught up on the accumulated backlog. Due to the longer than expected time away from the prison, I ended up losing the cell that I had occupied ever since 1976 . The prospects of a speedy return to R-1$\mathcal{N}$ tier are dim; one of the quietist at the prison. Considering the setting, it is a damn good tier. Currently, I am assigned to S-1-N 2, fowever, I aim to make my stay on $S$-wing as temporary as possible. I am striving to get back onto R-wing $\mathcal{A S A P}$.

The fearing, commencing on 3/6/80, lasted three days, ending on 3/10/80. There was in excess of a week's delay while awaiting transportation back to the prison. Normally, Death Row prisoners are moved on a priority basis due to the so-called security risk.

Regrettably (sic), portions of the Dean ineffectiveness issue did not turn out as well as we had fioped. On the other fiand, we seemingly strengthened the Windsor ineffectiveness. In addition, there are many variables which are unknown quantities that further complicate interpretation of where we stand, including; 
Journal of Prisoners on Prisons, Vol. 3, No. 1/2, Spring, 1991.

(A) Iudge Kyle's viewpoint with regard to the presented testimony nor the weight she'll attach to it, and (B) where Kyle stands on the other nine points for which no additional testimony was necessary. Iudge Kyle's attitude seemed very fair to both sides throughout the hearing. I hope her posture of fairness carries over into her decision-making. It is a rather frightening (sic) realization to acknowledge the extent that the State is trying so hard to execute me. This fact is vividly demonstrated by the active participation of five State Prosecutors at the hearing. Each member of their team had a specialized role in the presentation. Except in the Spenkelink case, this figh intensity level by the State attempting to execute someone has $\underline{\mathcal{N} O \mathcal{T}}$ been present in the other cases. Regardless of the reason, to be candid, this intensity scares the hell out of me.

Because parts of the Dean ineffectiveness did not go well. Ray shared my suggestion that we ought to regroup. We will attempt to improve our legal status on other points so as not to put all our eggs in one basket. Besides the improved Windsor ineffectiveness issue, there are several other solid points among those matters on which no additional testimony was necessary. On paper, the grossly misleading and erroneous McLaughlin polygraph reference is most likely our strongest legal point. Even Denis Dean testified that $W_{\text {indsor }}$ was ineffective and that my arrest was improper. Nevertheless, Dean's lies left me very depressed.

Let me detail for you what legal steps lie ahead of us. Many months, perfiaps even a year or more, will pass before we can expect a final $\mathcal{F} D C$ ruling. We are now awaiting the transcribed fearing transcript which is due on 4/4/80. Both sides must file by $5 / 2 / 80$ their respective memorandum of Law - the legal term meaning to apply the facts and testimony presented to the law. Both sides also will file a response-brief to the other's legal argument to be filed by 5/16/80. Once these stages fiave been completed, Judge Kyle can make her recommendation to Judge Gonzalez. The recommendation will be revealed to both sides so that response briefs can be directed to Iudge Gonzalez. Afterward, it will be totally up to the latter's discretion when and fow to make the final FDC disposition. Waiting surely will not be easy!! Thereafter, whichever side loses will appeal that ruling 
to the 5th Circuit Federal Court of Appeals (FCA), located in New Orleans.

I thought you might be interested in learning about what transpired at my hearing. Once again, I'd like to sincerely thank you for sending me the package which arrived just prior to my leaving for the fearing. The feadphones really are coming in extra-helpful here on $S$-wing because it is so noisy.

Keep in touch.

$\mathcal{A} s$ always,

Bob

April 8, 1980

Dear $\mathcal{N}$ ancy,

Thank you for your letter which arrived last night. As always, it is good hearing from you, Even though there isn't a whole lot of legally related news of substance to share with you, I wanted to write you before I received my hearing transcript. Our weather is getting much warmer hereabouts; the period from May thru September is very fot and uncomfortable in these small cells. As for myself, I am well and in good spirits. I spent a unwanted exile on $S$-wing until last Friday when I was moved to R-1-S-9. However, I ended up on R-1-S, the noisiest R-wing tier. I am still pressing as hard as possible to get back on $R-1-\mathcal{N}$ tier.

In order to be ready to give my undivided attention to our brief drafting, I am caught up on all backlogged work. Anxiously, I am awaiting my copy of the hearing transcript so that I can carefully review it. $\mathcal{M} y$ aim is to give Ray all the input possible to aid him in the preparation of my Memorandum of Law to Judge Kyle.

You may be amused to know that Denis Dean had the boldness to send Ray a bill for his court appearance at which time he clearly was not for me. Both Ray and I are still highly depressed 
Journal of Prisoners on Prisons, Vol. 3, No. 1/2, Spring, 1991.

by the actions of my former lawyers and their active collusion with the prosecution. I can accept defending one's actions (or lack of same) in a truthful manner as a reasonable reaction, however, when State witnesses calculatedly and frequently lie, it becomes very depressing ob discouraging. Presently, Ray is engaged in legal research into a number of areas of my appeal in order to try to 6olster our legal argument on various appeal points.

Tony Amsterdam wrote me that a U.S. Magistrate ordinarily will take from 3 to 6 weeks after briefing, which is scheduled to be completed by May 16th, to issue the recommendation. However, there is no specific rule of thumb. Wide variations are commonplace. For example, you may recall that Willie Darden's death warrant was signed on the same date as Jofin Spenkelink's. Anyway, Darden had a Federal evidentiary hearing in October, 1979, before a U.S. Magistrate in Tampa. He is still awaiting a recommendation? $\mathcal{A} t$ his hearing, the State was represented by a single prosecutor. Like me, Darden also raised ineffective counsel claims too. I am still disturbed by the State ganging up on me by sending 2 judges and 5 prosecutors to my hearing. I am naturally wondering why so many? The State may simply want me as its sacrificial lamb, something I've felt for a long time. Or they may have sensed that we're moving closer to being able to prove my innocence. The egos/reputations/etc. of the persons responsible may prefer that I am executed, rather than the State acknowledge that I was wrongly convicted.

I frope Iudge Kyle issues fier recommendation sooner as opposed to later. In all likelifiood, Iudge Gonzalez will follow Kyle's recommendation. Naturally, we want/hope to win at this stage, nevertheless, there always is the possibility that we could lose, which must be considered also. Thinking positively, I will defer further comment on future legal proceedings pursuing either these same appeal issues and/or other new points until a time that such speculation is more appropriate. By the way, there are many legal options that are left open to us. As I mentioned in my last letter, let me reassure you that we are still very much in the ballgame, seeking a new trial. Like in baseball, we must play this 
legal game for at least 9 full innings or stages and we're only in the 7 th inning.

Effective as of 4/1, our package permit policy has been revised from one per month to four annually - two at Xmas and two for the entire remainder of the year. As a result, I may have problems getting in sufficient stationary supplies for correspondence, general writing, and legal work. If the need arises to supplement either paper and/or envelopes, I fope that I can call upon you for assistance? Your package, which is much appreciated, will tide me over for awhile, although not indefinitely.

I am glad that you and Larry had the opportunity to read the Relling Stone article and found it to be so good! I feel that it packed quite a message for the reader. The vast majority of reaction has been very favorable. I hope that I never have to go through that again!!

What does pre-registering entail? It sounds good in theory. I recall all the fiassles while attempting to register myself, especially coming later in line when classes start to get closed out.

Even though it appears it will boil down to Carter vs Reagan, I hope it doesn't. Kennedy appears to have the only chance to unseat either one, and he must start with a strong win in Pennsylvania or he's through too. If John Anderson who I like, runs as a 3rd party choice it will make it easier for Reagan to win, I feel. Although baseball will start tomorrow, I am not optimistic of a strike-free season. I remain a die-hard Red Sox fan and feel they will be in the thick of the A.L. East race, Gaseball's best division.

Keep well, and,

As always,

Bo6 
Journal of Prisoners on Prisons, Vol. 3, No. 1/2, Spring, 1991.

June 10, 1980

Dear Nancy,

Your card reached me safely; it was good to hear from you once again. On a hot muggy afternoon, I am well and in good spirits except for re-aggravating an old back problem. It has been in the figh 90s for the past several days. This lower back strain flares up from time to time. This is a mild pull compared to the severe strain that I experienced last gune. $\mathcal{M} y$ major problem was getting to the clinic for some attention. I finally made it there earlier today after several days of attempts. I would surely hate to develop a serious injury or illness while confined to prison due to the lousy treatment available. The majority of the doctors are unlicensed foreigners too.

After several unsuccessful attempts, I finally reached Ray Black at home last Tuesday night. Having not heard from fim in over a month had left me climbing the walls wondering about my Federal brief, etc. Ray is recovering from eye surgery which explains why I had not heard from fim. As a result my appeal briefs have been further delayed until Ray's sight sufficiently improves whereby he can read. Previously, at the State's request we accepted the first filing date extension. Ray hopes to have the brief completed within 7 to 10 days. The long silence had left me unsettled. I truly wish that I could relax while accepting that no news is good news, but I cannot because I am too much of a worrier.

There was considerable media news involving capital punishment matters when the Potts execution drew nearer last week. Both Potts in Georgia as well as another inmate in Virginia each relented by deciding to permit their respective lawyers to appeal their cases to the Federal Courts. Yesterday, however, I heard that Potts has reversed himself again and now he wants to be executed! Anytime a death row prisoner demands to be executed, a state can legally accommodate the individual by pursuing $\mathcal{F e d e r a l ~ a p p e a l s , ~ i t ~ e n a b l e s ~ t h e ~ i n d i v i d u a l ~ t o ~ l i v e ~ f o r ~ a t ~}$ least 2 to 3 more years instead of facing a fiorrid death by electrocution. Positively, Potts managed to generate considerable media attention to focus onto the terrible living conditions and 
inadequate medical treatment available to those on Georgia's death row. I was interviewed by $\mathcal{A B C}$ 's Nightline Show regarding the carry over effect onto other capital case appeals had the execution taken place. The segment was aired on 6/4/80.

Otherwise not a whole lot is happening which makes daily life rather boring and dull. I am working on a new defense fund organizational chart necessitated by Barry Weaver's forced reduction of fis defense fund responsibilities due to severe time limitations. Ralph Jacobs will assume Barry's role. Also, we are drafting a new updated defense fund statement and preparing our annual report for distribution to those persons who are interested in defense fund activities. Lastly, we are in the process of mapping out some fresh defense fund objectives. In part we must try to promote greater media exposure, particularly with a emphasis toward acquiring some support from Catholic publications.

Presidential races always arouse my interest. Things will simmer down until after the conventions. In an informal poll the majority of my friends have indicated that they probably will vote for Anderson instead of either of the two party nominees. I would vote for Anderson myself unless Kennedy can somehow wrestle the Democratic nomination from Carter, which seems doubtful at best. When you decide on who you prefer, I'd be interested in learning of it and why? Based upon the early polls, Reagan should carry Nebraska.

I hope that your visit to $\mathcal{N}$ orth Carolina was a pleasant one. Let me thank you again for your package - it was greatly appreciated.

Write when you can.

As always,

Bob 
Journal of Prisoners on Prisons, Vol. 3, No. 1/2, Spring, 1991.

June 30, 1980

Dear $\mathcal{N a n c y ,}$

Thank you for your latest letter. On Saturday, my fiometown defense team held a benefit dance. I am hopeful that it succeeded financially, but most of all, I hope that everyone had a good time. It is reassuring knowing that friends care about me sufficiently to put on something of this kind in my behalf.

I seem to be feeling more spirited and as a result, I am emerging from my slump. Earlier in the month on $6 / 25$, it marked the first anniversary date of my Stay Order issuance by Judge Gonzalez. Other than the Federal Hearing, not a whole lot additional has transpired during this 12 month stretch. Actually, I must admit that I am very tired - tired of prison, tired of the same routine, tired of the same frustrations, and plain tired of waiting. But I'll get myself regrouped and somefiow hang tough because there is no other choice.

Already, I am counting the days until the cooler weather returns in the fall. This hot weather is ideal for our yard periods, but it is oppressive to have to live with it all day sweating since we only get to shower every other night for five minutes. Of late while in the yard, several of us have begun playing and enjoying badminton. $M y$ partner and I are the best doubles team having lost only 8 out of the last 41 games played. Not bad for a person who'll be 33 next month.

As you know, a recurring lower back problem has plagued me for sometime. I have concluded that much of the problem's source has been caused by sitting in a poor posture for so much of the day while writing etc. I would sit on a blanket on the floor in a semiyoga position while using my bunk as a desk top for upwards of 10 to 12 hours each day. This position would put excessive amount of strain on my lower back area particularly since there was no back support. № doubt, this posture has weakened by back muscles over the years, I suspect. I have arranged a new setup whereby I now sit on my bunk using a box positioned to my right as a writing surface. Also, I have a bound stack of newspapers and a blanket befind me which gives my back solid support, and two boxes sitting on top of each other which provide 
sufficient space on which I place my writing supplies. I commenced using this method on $6 / 22$, and I can feel the improvement both in my lower back and my legs. I really hope that this method continues to work out well because this is one problem that I'd like to overcome.

There is no further word from Ray Black about the status of my appeal brief filing. He is still recovering from eye surgery which will delay the filing of the brief until he can resume work. Virginia Snyder (our PI) is currently working on a few angles including persuading $M$ cLaughlin to talk to fer, and seeking a third alibi-type witness. Keep your fingers crossed. The USSC is winding down its current term with some encouraging capital punishment rulings news, the best of which found Alabama's capital punisfment law unconstitutional. Even though the USSC is making it farder to execute anyone involuntarily, the court has done nothing to benefit $\mathcal{F}$ lorida capital cases. Another good omen was the FSC Stay Order issued to Potts on Saturday.

I read where Carter's popularity rating fias slipped to a mere $30 \%$ and if the election were held today, Reagan would be our President, God forbid! There still is much time until $\mathcal{N o v e m b e r}$ for Carter to stage a recovery. I also read where political analysts prayed that John Anderson will either be a total flop or be a definite success capturing at least ten states, I'd prefer the latter. Believe it or not, the Republicans stand a fair chance to gain control of the US. Senate which would be quite a switch.

Please keep me posted on any address changes as they occur. Glad to hear your vacation to North Carolina was so good.

Keep in touch,

As always,

Bob 
Journal of Prisoners on Prisons, Vol. 3, No. 1/2, Spring, 1991.

INSTITUTION

NAME

JOB ASSIGNMENT Death Row

FSP
Robert A. Sullivan

CELL NUMBER $\underline{\mathrm{R}-1-\mathrm{N}-17}$

NUMBER

DATE $\underline{039870}$

$\underline{8 / 10 / 80}$

\section{Dear Nancy,}

How are you? It was good to hear from you once again. I am including a form-style memo for your perusal which fully describes the current status of my case/appeal and the anticipated delays reported in some detail. Other than a normal amount of discouragement associated with the realization that it could take as much as another year or more before us receiving a ruling on my case from Iudge Gonzalez. I am well and in good spirits. I guess that I should be used to the legal delays encountered after all these years, and yet.....! I am confident that I will come around after I adjust to this delay. I suspect too that it is mentally unwise to build up my hopes for a new trial, but that expectation is something that I cannot seem to control.

Tomorrow, the Democrats will commence their battle on rules and platform issues. Even though it appears certain that $\mathcal{M r}$. Peanut will secede the nomination no matter what evolves on the rules issues. I would surely prefer to see an open-convention. If the latter becomes a reality, it would definitely add some flavor to the convention dramatics. During the days ahead, the matter will unfold.

This hopefully will reach you at your new address? Please advise if I have it accurately? I hope that you enjoy your return to $\mathcal{N}$ (E. Keep well, and,

As Always,

Bob 
Laurence French and Nancy Picthall-French

\section{RAS MEMO \#81 $\quad 8 / 10 / 80$}

\section{SUBJECT: Case Update}

On this the eve of the Democratic Convention, I am simply striving to send this case update to you thru the quickest means available. Between a strained back and working hard on some legally related requests from both Ray and Virginia, I have fallen behind on keeping you updated which is why I am resorting to memo form while the news remains current.

The majority of the information which follows resulted from my phone call to Ray Black on $8 / 1 / 80$. We conversed at length for over 45 minutes. Having not heard from Ray since early June, this was a much needed discussion from my standpoint in order to calm my nerves. In case I had not informed you, Ray underwent major eye surgery in May which placed the filing and preparation of my appeal brief in a holding pattern. Ray is feeling much improved both in spirits and physically, even though his eye won't be fully healed for two (2) more months. He's been through the wringer himself during the past 18 months confronted with a series of personal and health problems.

The appeal brief which has been delayed due to Ray's eye surgery is the post-hearing memorandum of Law that presents our legal argument for Judge Kyle's consideration. Nevertheless, Ray hoped to be able to meet the current filing extension deadline which was $8 / 8 / 80$. The unavoidable postponements will not have any bearing on the outcome of the proceedings. In fact, Ray remarked that Judge Kyle has been both understanding and cooperative. Once the memorandum of Law has been filed, Ray suspects that Judge Kyle will take a few months before she submits the recommended ruling to Judge Gonzalez.

There probably will be another delay that you should know. Judge Gonzalez, according to Ray, has only recently commenced a trial which estimated to last 9 months duration. Therefore, Ray feels it is unlikely that Gonzalez will begin work on my case until after the trial concludes. Whether I like it or not, I have no choice but to accept it and try to be patient during the long waiting period. Once Kyle reveals her recommended ruling, we will have a strong indication of Gonzalez's eventual disposition. 
Journal of Prisoners on Prisons, Vol. 3, No. 1/2, Spring, 1991.

So far, three Florida capital cases have already received some action from the federal courts. The cases of Henry, Proffitt, and Raulerson, all either have received or been recommended for new sentence hearings. The issues raised in my behalf certainly appear to be of greater substance than any of the above listed cases. Therefore, some type of relief seems justified. As you know, my goal is a new trial as opposed to any lesser relief.

Positively, Ray continued to express optimism that relief is warranted on this appeal level. Along this track, Ray requested that I send him a detailed memo outlining all of the key areas which I feel are in need of additional investigation by Virginia as our fund raising permits. Primarily, of course, the main application of all favorable investigative results would be used at a new trial. The other possible use would provide me/us with an ace in the hole furnishing the vehicle for a second federal habeas evidentiary proceeding should the current round of appeals end in failure. Naturally, I will keep you posted of future case developments.

\begin{tabular}{lllr} 
INSTITUTION & FSP & \multicolumn{2}{l}{ CELL NUMBER $\underline{\underline{R}-1-\mathrm{N}-17}$} \\
\cline { 2 - 3 } NAME & Robert A. Sullivan & NUMBER & $\underline{039870}$ \\
JOB ASSIGNMENT & Death Row & DATE & $\underline{11 / 17 / 80}$
\end{tabular}

Dear $\mathcal{N a n c y ,}$

It was good to hear from you once again? I sincerely hope that this finds you well. I have been rather depressed lately, but my spirits are on the rise. You will better understand why my spirits have gone on a roller coaster ride once you read the enclosed updates \#5 and 6 . This is one prison experience that I surely would have preferred doing without, fowever, now that it is here, I must deal with it and try to recover from it. I am naturally still disgusted over the losses particularly the legal materials, some of which are irreplaceable. The results of the lawsuit should be interesting, most especially the outcome of the portion of the lawsuit which focuses upon the destruction of legal 
materials vital to individuals' cases. My ability to effectively assist Ray has been diminished considerably.

Well, it is now President-elect Reagan. I fope that the nation can survive the next four years. I also hope that Reagan's policies are more moderate than most of his conservative political rhetoric. Although I do not radically oppose Reagan's positions for a stronger foreign policy, reduced inflation and unemployment, $a$ balanced budget and better defense, nevertheless, I am gravely concerned by his stand on social issues. For example, Reagan is an ardent supporter of capital punisfiment. Moreover, Reagan's Presidency could directly effect me thru his appointments to federal judgesfips including to the U.S. Supreme Court. I really do not believe that there is any simple solution to the nation's economic and foreign problems that a change in power would remedy. Therefore, it will be interesting to compare the achievements of the Reagan administration to his campaign promises.

How do you analyze Carter's huge loss as well as the defeat of so many liberal U.S. Senators? Obviously, there is a shift toward the right, nonetheless, I do not believe that the shift is as great as the election tabulations suggest. I suspect that the voters were frustrated by the combined economic, energy, and fiostage woes, and took their disgust out on the party/people in power. When the pendulum starts to swing back toward the left, it is my fope that Ted Kennedy seizes the opportunity to become the leader within the Democratic party. In addition, the Democrats need to get back to basics through the concentrated strengthening of the party groups commencing at the grass roots level. What is your feeling about those who term themselves the moral majority and their dab6ling into negative politics?

Yes, you had sent me your change of address and I had sent you a letter thereto shortly after your estimated arrival date as I recall. Perfiaps the letter went astray. Anyway it is good to be able to resume contact with you once again? I can well understand your enjoyment over having returned to $\mathcal{N e w}$ England. I can assure you that I'd love to return there and I may never leave. 
Journal of Prisoners on Prisons, Vol. 3, No. 1/2, Spring, 1991.

Enjoy your temporary retirement so to speak and good luck getting a job. I fope that your folidays are enjoyable.

As always,

Bob

\section{RAS UPDATE \#5}

This update will exclusively be devoted to describing a disheartening prison experience. I doubt if most people (like I use to feel myself) have any idea what goes on behind prison walls. Other than what I'll relate below, the only worse prison experience was my warrant signing. Let me retrace what occurred, something I feel was unnecessary.

It all started on 10/12 when an officer was stabbed and killed on R-2-S tier of death row. Several restrictions were inaugurated almost immediately. Yard and canteen were suspended. Having to be handcuffed behind one's back anytime that someone in lockup leaves their cell generated the greatest resistance due to obvious safety reasons. This administration grossly over-reacted to a single isolated incident which was caused when the inmate had been refused to be allowed to visit with his mother, their first reunion since 1975.

Various protests erupted on several wings, but not on my tier. Riot squads using tear gas were called upon to quell any disturbances. On 10/12, two more officers were stabbed and scalded respectively by inmates on S-wing. I do not condone such violence, nevertheless, I surely can relate to the frustration that caused it. A repressive administration is the root problem source, and their over-reacting compounded the situation.

Interestingly, no changes were implemented while ten convicts were murdered during a 18 month period. Officers from other nearby prisons were called in to conduct a prison-wide shakedown. But this was not like any previous shakedown. It was more like grand theft. Over a 7 year period, I had accumulated 12 boxes of possessions which I stored neatly under my bunk. The vast majority of my losses were legal items. All were allowable items consisting of canteen, packages, and 
legal materials. Totally, at least $20 \%$ of my personal property was thrown out!

It will not be easy to replace my property nor conveniences due to tightened security. Moreover, packages have been reduced from 12 to 4 annually. But I'll make it. Please try to include extra stationary and stamps with your letters to me. Thank you.

Those who shook down my cell left it in a shambles, I have been exploring avenues available to me in order to recover damages for every item taken from me. This unjustified reprisal was shakingly calculated. Normally, a shakedown involves officers thoroughly inspecting one's cell and property for contraband. Never before did the staff so totally disrespect our possessions by throwing out whatever they desired. Every item taken from my cell was an allowable item consisting of legal materials, items that I had purchased thru the canteen, or received via approved package permits. These actions violated the prison rules as well as my rights. I feel that the nature of the shakedown was designed for revenge.

This harassment certainly was depressing. We were not even extended the option (prison policy) of being allowed to send items home. Nor were customary receipts given out (policy again) listing all items removed from a man's cell. Tier mates informed me that officers were laughing as they pitched my belongings into trash cans. I surely hope to have the last laugh. While my cell was being looted and ransacked, I had been removed in handcuffs to the quarterdeck for a haircut. Technically, the state ought to be responsible to pay for damages, a point echoed by Ray Black. This is another example of what causes tensions to explode in prisons. Most people blame the convicts but usually it all relates back to the keepers. 
Journal of Prisoners on Prisons, Vol. 3, No. 1/2, Spring, 1991.

\section{RAS UPDATE \#6}

In update \#5, I was definitely upset by being robbed (for all intents and purposes) by prison guards during a so-called contraband shakedown. What they did, not only to myself, but also to the majority of my peers, was totally unjustified. But I kept my cool deciding instead that the best means to get back at them would be thru a lawsuit. The primary objective would be, of course, to recover damages for all losses.

The items taken which disturbed both Ray Black and myself the most, was the destruction of over 2000 pages of personal legal documents as well as the confiscation of over 15 personal law books. Countless court rulings prohibit (in theory) the guards from taking any of our legal papers or resource materials. Nothing at all that was removed from my cell falls into the category of contraband. I will be able to replace most but not all of the confiscated legal materials. We intend to try to require the state to assume the responsibility for replacing every item taken, including legal.

Getting to the point, on $10 / 31$, a class action suit was filed in the Jacksonville division of the Federal Courts regarding the shakedown. I am among the ten named plaintiffs in the lawsuit. The charged defendants include the Governor, the Head of the Department of Corrections, and all prison staff who ordered or participated in the shakedown.

The suit seeks monetary damages for ourselves as well as injunctive and declaratory relief for the petitioners and all others similarly situated. Our suit charges violations of several amendments to the U.S. Constitution. Lawyers seem to project that we are on solid legal footing because it violates the law. In addition, the officers during the shakedown violated prison policy pertaining to possession of legal material, personal property, and of cell inspections clearly and deliberately. Plainly, they didn't give a damn.

Our lawsuit requests a jury trial, and seeks punitive damages in excess of $\$ 100,000$ bucks. Ray is not directly involved with the suit itself, however, he is fully appraised of the content. Indigent prisoners whose civil rights are violated can be assisted 
by the state funded Florida Institutional Legal Services. Their lawyers prepared and filed the lawsuit and will pursue it vigorously whenever the court agrees to hold a hearing on the case.

Probably, there will be a preliminary hearing within a few weeks time, however, final disposition may not come swiftly. An out-of-court settlement also is quite possible. It pleases me that prompt legal action is now underway, and that I am part of it. The local T.V. news even aired the announcement of the filing. I know that the prison administration may dislike any person associated with the suit filing, nevertheless, it is a matter of principle now. The expression, what goes around, comes around, is fitting. I don't expect any reprisals, but the possibility surely exists. This is simply one of those things that I had to do. The prison staff needs to be shown that we will not tolerate them to steal/destroy our property. It is my turn to have the last laugh. My total losses, including replacement estimates of all legal matter, could exceed $\$ 1500$. That is a lot of money to me, but transcripts and law books are very costly.

Things at the prison are calmer, however, it is a tense situation still. All of the new security changes as well as the increased staffing per wing remains in effect. I can make adjustments to those revisions all right. The canteen has been running, but not on schedule whereas the yard curtailment is much more extreme, I've only been allowed outside twice within $31 / 2$ weeks. I doubt if things will ever return to normal again. 
Journal of Prisoners on Prisons, Vol. 3, No. 1/2, Spring, 1991.

March 22, 1981

Dear $\mathcal{N}$ ancy,

How are you? I received your card around Xmas. I have been swamped lately with assorted time consuming matters and desiring to keep up pace with my correspondence, I concluded that resorting to the enclosed form-style general update to report on repetitive subjects was the only effective means to get ahead of the game at this time.

I trust that you can sense and imagine my excitement regarding the prospect of really establisfing contact with my birth mother. This subject really has kept my mind churning as it is certainly dominating my mind. Nevertheless, I am moving afiead with very mixed emotions, experiencing both excitement and fear. I am troubled also by anxieties fearing rejection for a second time.

Because my previous family life left so much to be desired, this reunion has become even more important to me. $\mathcal{M} y$ parents separation occurred when I was only six and followed by the traumatism of being shuttled between two parents who thoroughly fiated one another, made it a rough, mental period. Therefore, it is my sincerest fiope that my mother and I will succeed to work things out whereby our friendship can grow and develop greater meaning as time passes. Wish me luck.

Please keep in touch, and,

As always,

Bo6

\section{ATTACHED}

Let me try to bring you up to date with recent happenings. I had intended to write prior to the postal rate increase, but I didn't make it. I continue to be well and in good spirits, despite some past extraction discomfort having had an abscessed wisdom tooth extracted on $3 / 16 / 81$. Beforehand, the pain had literally knocked me to my knees so the extraction brought me much relief.

Legally, my case remains resting in Judge Kyle's lap. At some future point, she will issue a non-binding recommended 
ruling for Judge Gonzalez's consideration. Neither judge is bound by a deadline. Therefore, I suspect this two-step ruling procedure to consume most of 1981 , if not longer. We remain optimistic that legal relief can be achieved on this level, however, nothing is guaranteed. Neither is there any advancement on either of the two federal-class action lawsuits in which I am a plaintiff. No hearing date has been set on the shakedown. The only matter resolved on the suit seeking more outdoor exercise opportunity, was a ruling in which the judge rejected the state's motion to dismiss. The name of this legal game is ......waiting!

I have heard, interestingly, that Edward Cowart has resigned as a judge to move to Nevada. Because of his deep prejudice toward me, I consider it good news that Coward is leaving the State. In 1977, Cowart amazingly wrote to the Clemency Board threatening to resign as a judge unless my death warrant was signed. I surely hope that his resignation will be a positive omen regarding my appeal? Another incredibly unjust development is the fact that McLaughlin was scheduled to have been released on parole on $3 / 14 / 81$.

A promising appeal issue came to my attention, ironically, while attempting to re-write my case notes that were taken during the shakedown. It appears that we might have a solid "conflict of interest" claim. Briefly, while Denis Dean represented me, he simultaneously was the permanent retained counsel for the Dade County Police Benevolent Association, members of which were prosecution witnesses. Lawyers are compelled to disengage from any legal activity in which divided loyalties potentially could exist.

March has been an event-filled month for me during both 1980 and 1981. Last year, I had my federal evidentiary hearing before Judge Kyle, and I became a published author thru my Rolling Stone article. March 1981, has been eventful for me as well, despite the abscessed tooth and worry about Steven Judy's execution.

This month started out well for me with a rare social visit on $3 / 1 / 81$, followed by an attorney visit on 3/3/81 from Deborah Lins of the LDF. The new appeal issue also surfaced during this 
Journal of Prisoners on Prisons, Vol. 3, No. 1/2, Spring, 1991.

month. And it certainly never hurts to try to develop a stronger defense argument. There is one other achievement of a personal nature. On $3 / 13 / 81$, I received explicit confirmation that I have located my birth mother. This was affirmed after a lengthy, frustrating search.

Coincidentally, but for different reasons, both my mother Eleanor, and I have interjected a liaison person. Realizing that I have finally located her is quite satisfying, however, these next steps could be more difficult. Naturally, I desire a reunion, There are many mountains yet to climb. My liaison person, Father Boyle, a trusted friend, will do his best to represent my interests. I am, of course, very apprehensive wondering how she'll react to me especially after she learns that I am on death row. I do not envy Father Boyle's difficult role nor the decisions that Eleanor faces. I shall try to wait patiently, hoping and praying for success and much happiness for everyone involved.

During the months ahead, my hometown defense fund group intends to conduct its second raffle. They hope to appeal to the entire defense fund network, resultingly you should hear from them prior to the summer. I'd welcome any suggestions that you might have to aid us to more successfully implement this venture via the mails. Please feel free to give me/us any input on our project that might help. Many thanks! 
Dear Nancy,

Greetings and frow are you? All in all, I am well and in good spirits. The oppressive heat has abated a little bit whereby it is slightly more tolerable. I continue to keep myself busy trying to remain patient while waiting for a ruling on my appeal or on either of the two federal lawsuits.

There is some good non-legal news. On $7 / 20$, coincidentally on my 34 th birthday, I received a combined birthday card and letter from Eleanor. Therein, she indicated that she was starting to put her life back into some degree of order, and that she is overcoming the initial double-shock of being contacted out of the blue by the child who she gave up for adoption in 1947, and that the son is now sentenced to die. Eleanor advised me that we shall fave a reunion in the not too distant future. Soon, she'll commence making the necessary arrangements in order to be approved to visit me. Finally, I know that I can look forward to meeting my birth mother. I recognize that it probably will be an emotional visit for us both, however, I am wondering if you have any advice on the topic?

I have received Virginia's report describing fer $7 / 9$ meeting with Michael Carmack. There is no doubt whatsoever that Mike was $\mathcal{N}$ (E)'ER contacted by anyone before 1981 about my case. Because this is in direct conflict with Dean's testimony, it certainly should raise some question(s) regarding Dean's credibility. Mike is fully willing to testify thereto.

We also are working hard on the alibi with Mike. He could not positively identify my photo, but it did ring a bell. Our problem could have been only possessing photos from 1970 and 1979. Nevertheless, he does recall the night the crime occurred, including Billy Harlow's 18th birthday party. Now we must concentrate on linking me to the facts Mike recalls. There is a certain discussion(s), etc. recalled by Mike which took place on this same night. His recollections are exactly similar to what I wrote in 1973 that occurred between he and I. As the means to seek positive identification, I have suggested to Virginia that she bring Mike here to the prison. If Mike can identify me as the 
Journal of Prisoners on Prisons, Vol. 3, No. 1/2, Spring, 1991.

same person who he's described, we've then got our third alibi witness. Nonetheless, based upon past experiences, I shall not count my chickens before they're hatched. I must add that it seems like an impossible coincidence for Mike to have traced our discussions and my movements parallel to the facts which I've stated ever since 1973, without it being true, I dare to ask? Let's pray for complete success.

There have been several strikes and/or strike threats of direct concern lately. I am very distressed by the prolonged baseball strike. If it has not been resolved by mid-August, I fear that the entire baseball season will be lost. I am already gearing up to enjoy the football season, my favorite sport. Ralph gacob]s first report indicates that the initial response to the raffle has been encouraging. I pray that we reach our $\$ 3000$ goal so that we can carry on our investigation. Now that more fias become known about Sandra O'Connor, I am more skeptical of her philosophical views, nevertheless, I won't pre-judge her. An appointment of a woman to the USSC is long overdue. As an Arizona legislator Mrs. O'Connor voted for and assisted in the drafting of Arizona's death penalty statute. Not a good sign, is it?

It was good to hear from you again after a long time lapse. I wrote you a letter on 3/22/81 but apparently you didn't receive it based upon your letter. I log every piece of correspondence in or out. I didn't write more having not heard from you? I am glad the ice is broken. Did you recently receive word from my defense fund? I am glad that you've managed to get a new cat. I can relate to how you felt, having become attached to cats and dogs (latter mostly) myself. Your gardens sound quite nice too. long.

Hoping you are well and please don't stay a stranger for so

As ever,

Bob 
Dear Nancy,

Merry Christmas! I wanted to spend a little time with you on this Christmas morning. This is my ninth $X$ mas spent on death row. At least I have a good meal for which to look forward later today at dinnertime. I really get depressed around this time of year which I suppose is quite natural considering these grim surroundings. I don't even have any planned visit(s) to which I can look forward. Since my dad's last visit before his death on $2 / 1 / 79$, visits for me have been few and far between, which definitely can be discouraging.

I Keep froping and praying that Eleanor, my birth mother, will soon pull fierself together sufficiently to enable fier to visit me. I fonestly, had expected that she and I would have had our first reunion by this time, but we have not! I am not sure what to think anymore? or have I heard from Eleanor since 10/16, not even a Xmas card as yet. I do write to her regularly too. Interestingly, I recently noticed a photo in the Boston Globe which I believe to be fer. This prolonged silence has not helped my spirits one iota either. Hopefully, there will be a major breakthrough SOON. Any ideas?

While I am thinking of it, I am critically low on both stamps and envelopes. Could you please possibly send me some of eitfer, it would be greatly appreciated. Up to 20 can be sent without a permit. Thanks.

As you may recall, Virginia Snyder is the private investigator who works on my case as our funding permits. Besides working with our alibi witnesses, Tigle and Harlow, they also found Michael Carmack earlier in 1981 at long last. Carmack might turn out to be our most effective witness. Of course, Virginia is working on other projects in addition to the alibi. Anyway, what I've been leading up to is that Virginia's agency is tentatively scheduled to be featured on the $\mathcal{N B C}$ Today Show, on the morning of Thursday, January 7, 1982, between 7:45 and 8:00 AM. You might care to view it? I just hope that Virginia will strike paydirt on some current projects, the foremost being our efforts attempting to secure the cooperation of Thomas Murphy. 
Journal of Prisoners on Prisons, Vol. 3, No. 1/2, Spring, 1991.

Now that our brief appealing Gonzalez's negative decision has been filed, our correspondence level between myself and Ray Black has increased in tempo. This appeal now is pending before the 11th Circuit Federal Court of Appeals in Atlanta. I am reassured that Ray feels quite optimistic there, however, based upon my years of experience, I am forcing myself to guard my emotions carefully, Lawyers always find some reason to be optimistic. A great deal will depend upon the luck of the draw in the 11th Circuit. $\mathcal{A}$ very important factor will be the actual feelings of the three jurists who will comprise the panel of judges who will be assigned to hear my case. I don't think that we'll know the names on the panel until the actual oral argument presentation. Apparently, Ray believes that some new case law issued subsequent to Gonzalez's decision, made by this same 11th Circuit could place two of my appeal issues into a more favorable light. Please pray for our success.

Thank you for the card and letter. It was good to hear from you once again. Was glad to learn that you were able to locate a job which you enjoy. Your self-built home sounds very ambitious and yet self-satisfying. How long do you anticipate it will take before you can move in? Was sorry to learn of the passing of your grandmother.

Best wishes for a Happy New Year.

As always,

Bob 
January 17, 1983

Monday

Dear $\mathcal{N a n c y ,}$

Thank you for your Xmas greeting and note. Thought I'd drop you a line to update all the legal news. We've been having our coolest weather of the winter, which I enjoy. MMy spirits remain positive. I've really been enjoying all the T'V football games, plus last week I got to view one of my all-time favorite movies, "El Cid."

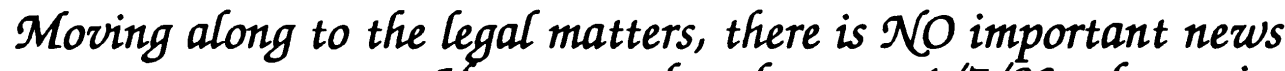
to report on my case. However, elsewhere on $1 / 7 / 83$, the entire U.S. 11th Circuit $\mathcal{F C A}$, ruled 6 to 5 to uphold Alvin Ford's conviction and sentence on all but one issue, the latter of which was returned to a federal district judge for further review. Ford's main issue had asserted his rights had been violated when the FSC (Florida Supreme Court) used SECRET prison psychiatric reports in its reviewing process of capital appeals. This was a farreaching decision due to the fact that it could have affected up to 123 cases, one of which was mine. We had always viewed the odds of relief for me on that issue were very slim. None of the other points on which Ford lost should adversely affect any of my appeal's main points. I do expect the 11th Circuit may soon move on to other pending appeals (my appeal could be one).

The issue on which the 11th Circuit sent Ford back to the federal district judge is legally similar to one of my points of appeal. Our facts appear stronger than Ford's tho. Ray Black examined the legal aspects of that issue in Tom Wiker's column (see back page of current newsletter that was mailed to you last month). I'll be keeping an eye on Ford's remanded issue. Even though that appeal point would be limited to a new sentence hearing, any form of relief at this point would provide some welcome and needed breathing room. № matter what, a new trial is our primary objective. Meanwfile, more investigation can be undertaken whenever affordable. We are very much in this contest. And if a second round of appeals is needed, unlike most other cases, we've located considerable new material to present to the courts. Even so, in order to succeed on appeal, I believe we 
Journal of Prisoners on Prisons, Vol. 3, No. 1/2, Spring, 1991.

must gather more exculpatory data, therefore our search for additional evidence must continue.

With every ruling involving a capital issue that it renders, the 11th Circuit creates the legal standards it will apply when reviewing all subsequent capital appeals. To see where one stands on an issue of law, one needs to study the parallel case law and apply it to the facts in a given case. Ass more rulings are rendered, the court's charted course in the application of death sentences should become clearer. Ford's appeal of LAST resort, appealing those issues which lost in the 11th circuit must go to the USSC (U.S. Supreme Court). I am not optimistic that the minimum requirement of 4 USSC Iustices that is mandatory for a case to be accepted for full review, will consent to such a review of Ford. The issue in Ford sent back to the federal district court should take no less than one year to fully litigate. Therefore, the odds of a 1983 Florida execution are reduced. Nevertheless, on a national level, I foresee notfing that could prevent a slow but steady rise in the rate of executions as more cases exfiaust their appeals, thereby slipping thru the system's cracks.

It was good to hear from you once again. Sounds as if the work 6uilding your house keeps you busy. Will it be finished in 1983? I am sure it is a lot of work, but the end result should be very worthwhile.

Keep in touch, and

Best regards,

Bob 


\section{EMERGENCY MEMO}

$\underline{9 / 22 / 83}$

\section{FROM: BOB SULLIVAN}

\section{TO: $\quad$ ALL MY FRIENDS}

Because time is at a premium, it is impossible for me to write to each of you personally at this time. Therefore, I had no choice but to resort to a form style memo. This memo will be a request that I sincerely hope you will consider and follow up quickly. As you know from the last RASLDF my case has moved to the appeal step of LAST resort, to the USSC (U.S. Supreme Court). It is very frightening to realize that I could be legally murdered as soon as November. In case the USSC rejects my appeal in October, we are racing against time in order to be prepared for every possibility in advance. The USSC's term starts on October 3rd.

As you may recall, we are re-organizing at this time. I do have new lawyers who have volunteered to represent me. Today, I met with one of my new lawyers, Steve Gey, for nearly five hours. We are trying to develop new issues to use in a second round of appeals if Governor Graham should sign another death warrant against me.

Among the new appeal points that we plan to raise will be charging that I was ineffectively represented at the sentencing phase of my trial in 1973 . We feel there was a wealth of very powerful mitigating material that was available to my counsel in 1973, but was never presented on my behalf for my jury and judge to consider about me as a person, my character, and the like. Based upon case law that has evolved over the years, we could have presented all of this material in mitigation of my sentence. In order to have any chance to win on appeal, it is essential that we be able to proffer in advance what was available but never even explored at that time by counsel.

Therefore, I desperately need your help at this time. We need affidavits from YOU, one that would clearly say whatever you might of felt was appropriate to tell a jury why I should NOT have been sentenced to die. Unlike our request for letters in 1979 to be used for clemency, this time it is mandatory that we have notarized affidavits. Due to the time factor, we need them 
Journal of Prisoners on Prisons, Vol. 3, No. 1/2, Spring, 1991.

very fast. We must get everything organized by early October.

Please consider sending my lawyer an affidavit. Although you should put it into your own words, let me try to guide you as to what would be the most help. As an introduction, be sure to clearly identify who you are, discuss your background, and say how you knew me. In the affidavit's main body, you should fully explain as many specific points that you can recall about me, that you feel could have provided information that might have helped my judge and jury to conclude that I deserved a sentence less than death.

Some areas that you may like to include, but please do not feel limited by them are as follows: (A) what you knew of and felt of me as a person; (B) your impressions of my future prospects to contribute to society; (C) good deeds; (D) my character; (E) if to your knowledge if I was a non-violent person; (F) discuss the emotional difficulties that I experienced due to being adopted, growing up in a broken home, and caught between two parents who hated each other and (G) anything else of a mitigating nature that YOU know about me that could possibly be helpful.

In your affidavit it is very important that you clearly state a few other points as well. Please be sure to clearly indicate that you would have been willing to testify to the above at the sentencing phase of my trial in 1973, however, NO ONE representing me bothered to contact you.

I deeply appreciate your consideration and hoped for participation in this effort. Believe me, we NEED your affidavit as it could help us to earn a stay and to gain a sentence less than death. I am sorry to rush you, nevertheless, we need these affidavits just as soon as possible. Be sure to have it notarized before you mail it. All affidavits should be mailed to my new lawyer whose name and address are listed below. Thank you very much for your cooperation with this urgent request. Also please share this with anyone else who knew me as of 1973.

As always,

Bob 
MAIL TO

STEVE GEY, ESQUIRE

c/o LAW OFFICES

PAUL, WEISS, RIFKIND, WHARTTON \& GARRISON

345 PARK AVENUE

NEW YORK, N.Y. 10154

phone (212-644-8666)

September 24, 1983

Saturday

Dear $\mathcal{N a n c y}$,

I sincerely hope this letter finds you well? I need to discuss a matter of grave importance to me with you. The latest newsletter accurately reflects the seriousness of my position. This letter's purpose is to compliment a memo which will be sent to you very soon under separate cover for your consideration. Although the memo is self-explanatory, I definitely wanted to send this personal plea to you as well.

Even though my status appears grim, we are $\mathcal{N} O \mathcal{T}$ quitting, and in fact, we are re-grouping legally. Since my present appeal, now in it's final step, could be rejected as early as October 3rd, we've added some new lawyers who are rusfing to piece together a second round appeal composed of $\mathcal{N}(\mathcal{E} W$ issues and/or material. But we are literally in a race against time.

Among the new appeal points, we are hastily trying to assemble, we want to re-open ineffective assistance of counsel at the sentencing phase of my trial in 1973. Any lawyer in a capital case should seek out and present every useful shred of positive mitigating material that can be found to put forth for the consideration of the judge and jury. Quite frankly, my appointed attorney's efforts at sentencing were extremely weak even though there was a wealth of relevant material readily available. 
Persons like yourself, we feel, could have been very creditable attesting to my good qualities, character, etc. For me to have $\mathcal{A N O}$ chance of winning on this issue or getting a stay, we MUST proffer in advance to the courts what my lawyer should have, but did $\mathcal{N} O T_{\text {present in my befialf. }}$

My new lawyers have asked me $\mathcal{L} E R Y$ quickly to try to secure as many affidavits as possible by persons who should have testified for me in 1973. I sincerely frope that you will help me at this time. $M y$ very life hangs in the balance. To help, simply follow the directions outlined in the memo that's coming to you under separate cover. In order to prevent the state's plans to execute me your/these affidavit(s) will be helpful. Also, if you know anyone else who knew me then who'd help us now, would you PLEASE share this plea with them?

In closing, let me thank you for your consideration of this plea, which for me is one of life or death! Also, in the event this is my final good-bye letter, I want to express my thanks to you for our friendship and all the memories associated with it.

Very sincerely,

Bob

P.S.

Some new literature enclosed $\mathcal{F} Y I$

On November 30, 1983, Robert A. Sullivan was executed. 


\section{REFERENCES}

Information used in the preparation of this material was secured from the following sources:

Campus, A. (March 6, 1980) "Interview with Robert A. Sullivan" Rolling Stone, 312 :49-52; 76-77.

French, L. (1980) "Boundary Maintenance and Capital Punishment" Behavioural Sciences and The Law, 5 (7):423-432.

Furman v. Georgia 428 U.S. 238, 345, 1972.

Gettinger, S. (Feb. 2, 1984) "Obit: Robert A. Sullivan July 20, 1947 - November 30, 1983” Rolling Stone, 414:60.

Larsen, R. (1980) Bundy: The Deliberate Stranger, New York: Pocket Books.

Walker, R. (June 23, 1983) “The Case of Robert A. Sullivan" WPC Case Report.

Woodward, K., et al. (December 12, 1983) "The Pope and The Death Penalty" Newsweek C11:77. 